\title{
PHARMACEUTICALS AND ENDOCRINE-DISRUPTING COMPOUNDS: ACCUMULATION IN THE TISSUE OF SKADAR
} LAKE FISH

\author{
DRAŽANA RADONJIĆ ${ }^{1}$ \\ ${ }^{1}$ Biology Department, Faculty of Natural Sciences and Mathematics, University of Montenegro, Podgorica, Montenegro
}

\begin{abstract}
Determining the presence of pharmaceuticals and endocrine-disrupting compounds in fish tissues has been carried out in Montenegro for the first time in Moraca river and Skadar lake. Skadar lake, Montenegro, is the largest of the Balkan lakes and has a surface area which fluctuates seasonally from approximately 370 to $600 \mathrm{~km} 2$. During the spring time of 2016, in the time of high water levels of the lake, fish were fetched in triplets and identified. Determining the presence of pharmaceuticals and endocrine-disrupting compounds in fish tissues has been carried out in Montenegro for the first time. Their muscle tissue was separated, grinded, feezed, and then lyophilized. Prepared samples were analyzed with liquid chromatography coupled to tandem mass spectrometry to determine the presence of pharmaceuticals and endocrine-disrupting compounds. Obtained results are under the border of detection, out of 38 tested distributes, only the tissue of Alburnus scoranza showed the presence of triclosan.
\end{abstract}

Keywords: Endocrine-disrupting compounds, Lyophilized, Liquid chromatography coupled to tandem mass spectrometry, Alburnus scoranza, Triclosan.

\section{INTRODUCTION}

In recent years, potential risks associated with the release of Endocrine Disrupting Compounds (EDCs) into the aquatic environment have become an increasingly important issue for environmental regulators. Several investigations have shown that the substances of pharmaceutical origins are often not eliminated during wastewater treament, and are not biodegradable as well (Ternes, 1998; Daughton et al., 1999; Zwiener et al., 2004). Due to the conservative nature of physiological processes, chemicals affect several aquatic species (e.g. algae, invertabrate and fish) in a manner similar to their affect on humans due to comparable target molecules (Fent et al., 2006). Many contaminants have been detected in wastewater effluents and surface waters in recent years, including pharmaceuticals (PhACs) and (EDCs). Many of these compounds are not completely removed in the wastewater treatment plants (WWTPs) and are released to the environment (Gros et al., 2009). EDCs are designed to modify physiological or biochemical functions in target organisms but can have severe consequences when non-target organisms are under their exposure.

Better understanding of how these compounds are transferred from water to the biota could help to determine potential ecosystem damage associated with the WWTP effluent discharge contaminants. It is generally accepted that substances with octanol-water partition coefficient $(\log \mathrm{KOW})$ values higher than or equal to 3 have the potential to bioaccumulate in biological tissues. Many PhACs and EDCs have a log KOW < 3, and thus are not expected to bioaccumulate. However, some of these compounds are lipid soluble and therefore potentially bioaccumulative in the environment (Huerta et al., 2013) and fish tissue. Moreover, when considering bioaccumulation of PhACs and EDCs in aquatic organisms, one must take other factors into consideration, such as the different rates of metabolism in various organisms, how their metabolites accumulate, and the uptake and depuration kinetics.

Situated along the Montenegro-Albanian border, Lake Skadar is the largest lake of the Balkan Peninsula with unique characteristics, wide range of endemic and rare or endagered plant and animal species, recognized as a wetland site of international significance according to the RAMSAR Convention (2002). In spite of its importance, inflowing waters from the Moraca river and other regional rivers contaminated by the industry, municipal and agricultural activities in the area influence the Lake. Therefore, the Lake has been the subject of various physical, chemical, biological and toxicological examinations (Beeton \& Karaman, 1981; Rastall et al., 2004; Rakocevic-Nedovic \& Hollert, 2005; Stesevic et al., 2007; Perovic et al., 2012; Kastratovic et al., 2014; Vemic et al., 2014; Petrovic et al., 2016, Perovic et al., 2019). In this study, we assessed the level of bioaccumulation of ECDs and PhACs in aquatic organisms (fish tissues) Rutilus prespensis (Karaman, 1924), Squalius platyceps (Zupancic et al., 2010), Scardinius knezevici (Bianco \& Kottelat, 2005), Chondrostoma ohriadunum (Karaman, 1924), Cyprinus carpio (Linnaeus, 1758) and Alburnus scoranza (Bonaparte, 1845).

\footnotetext{
* Corresponding author: i.radonjic99@gmail.com
} 


\section{EXPERIMENTAL}

\section{Area of study and sampling}

The research location belongs to the area of Skadar lake and its tributaries. Locations are marked on the Figure 1.

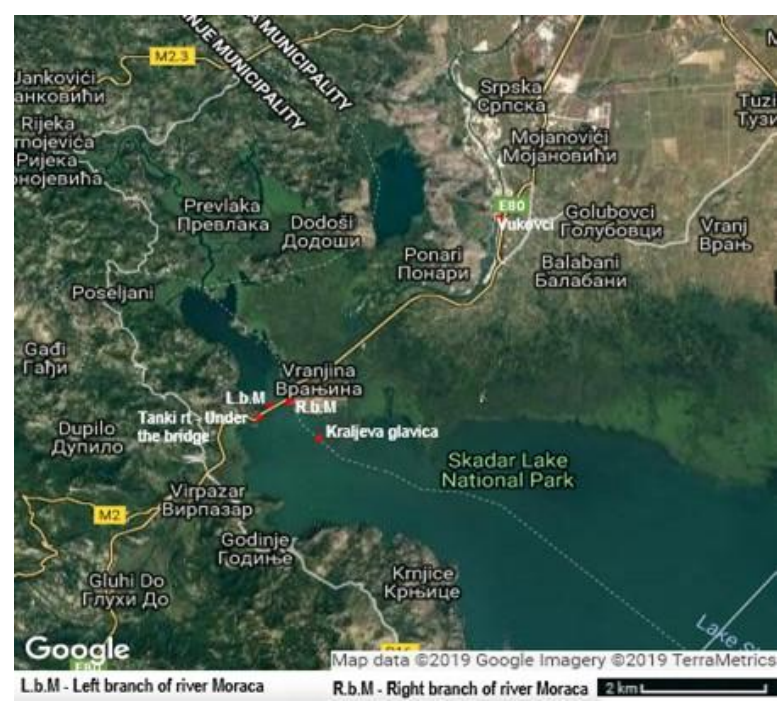

Figure 1. Map of Lake Skadar with sampling locations.

Lake Skadar is the largest lake on the Balkan Pninsula. It is located in karst area on the Montenegro-Albanian border and covers the surface from approximately 370 to $600 \mathrm{~km} 2$, depending on seasonal fluctations. This area is classified as an internationally important RAMSAR site (Lake Skadar, Site, 3YU003, Ramsar Convention 2002) and promoted as a National Park IUCN Category II. In spite of its importance, inflowing waters from the Moraca River and other regional rivers contaminated by the industry, municipal and agricultural activities in the area affect the lake. River Moraca (Mediterranean basin), near the town Podgorica, is relatively intact but still receives the treatment of waste water discharge, produced by 300,000 citizens. River Moraca emerges at the topographic point of $975 \mathrm{~m}$ above the creeks which disembogue under the Javorje and Zebalci slopes, with largest of them being Javor and Rzav creeks. River Moraca is $113 \mathrm{~km}$ long, which makes in the longest river in Montenegro. The researched locations with the coordinates.

Vukovci $42^{\circ} 20^{\prime} 02^{\prime \prime} \mathrm{N} ; 19^{\circ} 11^{\prime} 60^{\prime \prime} \mathrm{E}$, "Left branch of river Moraca“ 42 $2^{\circ} 25^{\prime} 84^{\prime \prime} \mathrm{N}$; $19^{\circ} 13^{\prime} 46^{\prime \prime} \mathrm{E}$ "Right branch of river Moraca“ $42^{\circ} 27^{\prime} 70^{\prime \prime} \mathrm{N}$; $19^{\circ} 12^{\prime} 32^{\prime \prime} \mathrm{E}$ "Kraljeva glavica“-Vranjina $42^{\circ} 27^{\prime} 57^{\prime \prime} \mathrm{N} ; 19^{\circ} 12^{\prime} 15^{\prime \prime} \mathrm{E}$ "Tanki rt" - Under the bridge $42^{\circ} 27^{\prime}$ $90^{\prime \prime} \mathrm{N}, 19^{\circ} 13^{\prime} 49^{\prime \prime} \mathrm{E}$.

Throughout decades, this locality has been under the influence of industrial waters originating from Kombinat Aluminijuma (CAP) and Machine Factory "Radoje Dakićc. Therefore, all researches were conductedin order to determine the concentration of PCB, aluminium, heavy metals and oil in water, land and biota. However, this industry slowly stoped working during the 90s. Podgorica and its surroundings make up for more than a half of the population of Montenegro. Therefore, waste waters are seen as the main pollutants of river Moraca.

\section{Animals and experimental design}

Samples were fetched in triplets using fishnets in spring of 2016, during the time of high water level of the lake, we separated musscle tissues and repeated the process 3 times, grinded them separatekt in a hand blender, put them into special sample boxes and froze them. Two days later, they were transported to the Marine Institute of Montenegro where they were lyophilized.

\section{Sample purification optimization}

Fish homogenate extracts were spiked with a mixture of the target analytes and a comparison was made between three purification techniques: SPE Florisil cartridges (1 g, $6 \mathrm{ml}$ cartridges), Gel permeation chromatography (GPC) in an Agilent 1260 Infinity high pressure liquid chromatography system in tandem with a diode array detector (HPLC-DAD), SPE Oasis HLB (200 mg, $6 \mathrm{ml}$ cartridges) followed by GPC. For the cleanup method based on SPE Florisil, fish extracts were redissolved in $10 \mathrm{ml}$ of acetonitrile prior SPE, which was performed in a J.T.Baker® system.

\section{Liquid chromatography and mass spectrometry analysis}

The cromatographic tandem mass spectrometry method applied for the analysis of fish extracts was adapted from Gros et al. (2009). Briefly, chromatographic separations were carried out with a Waters Acquity Ultra-PerformanceTM liquid chromatography system, using an Acquity HSS T3 column (50 $\mathrm{mm} \times 2.1 \mathrm{~mm}$ i.d., $1.8 \_\mathrm{m}$ particle size) for the compounds analyzed in positive electrospray ionization (PI) mode and Acquity BEH C18 column (50 mm $\times 2.1 \mathrm{~mm}$ i.d., $1.7 \_\mathrm{m}$ particle size) for the ones analyzed under negative electrospray ionization (NI) mode. For the analysis in PI mode, separation conditions were as follows: solvent (A) methanol, solvent (B) $10 \mathrm{mM}$ formic acid/ammonium format $(\mathrm{pH} \mathrm{3.2)}$ at a flow rate of $0.5 \mathrm{~mL} / \mathrm{min}$. The analysis in NI mode was performed by using acetonitrile (A) and (B) $5 \mathrm{mM}$ ammonium acetate/ammonia $(\mathrm{ph}=8)$ at a flow rate of $0.6 \mathrm{~mL} / \mathrm{min}$. The sample volume injected was 5_L in both cases. The UPLC instrument was coupled to a 5500 OTRAP hybrid triple quadrupole-linear ion trap mass spectrometer (Applied Biosystems), ; nitrogen collision gas (CAD) medium; source gases GS1 and GS2 were set at 60 and 50 psi, respectively. Besides the monitoring of the SRM transitions, the relative abundance of the two SRM transitions in the sample were compared with those in the standards, and the relative abundances in the samples must be within $\pm 20 \%$ of the two SRM ratios in the analytical standards. Prepared samples were sent to Catalan Institute for Water Research (ICRA)-Gerona in order to determine the existence of certain EmS and EDCs in the fish tissues using the (Huerta et al., 2012) and (Huerta et al., 2013) method. 


\section{NUMERICAL RESULTS}

Occurrence of PhACs and EDCs in freshwater fish is presented in table 1.

Obtained results are under the border of detection, or in the frames of the method detection and quantification limits (MLD, MQL). Out of 38 tested distributes, only one (triclosan) was founds in the muscle tissue of Alburnus scoranca in

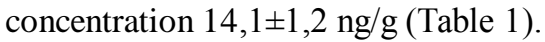

Triclosan phenol, are commonly used commercial microbicides found in toothpastes and soaps. Triclosan (is widely used as an antibacterial agent in various industrial products, such as textile goods, soap, shampoo, liquid toothpaste and cosmetics, and often detected in wastewater effluent. However, there is a paucity of data on the toxicity of triclosan and its effects on aquatic organisms. For example, (Tatarazako et al., 2004) in his observation found that concentration of fish (Danio rerio and Oryzias latipes) was from 0.07 to $0.29 \mathrm{mg} / \mathrm{l}$. Other scientists have studied the toxicity of triclosan too, especially because of its wide spread in chemical industry. For example, Ximei et al. (2013), researched assessment of toxic effects of triclosan on swordtail fish (Xipophorus helleri) using a multi-biomarker approach. Another example is the research of triclosan in Fresh Water Fish Gibelion Catla from the Kaveri River, India, and its Consumption Risk Assessment (Govindarej et al., 2014).

Of note, while fish can be exposed to higher levels of triclosan from their surroundings, algae and invertebrates are often considered more sensitive Chalew \& Halden (2009). A number of different aquatic toxicity thresholds for triclosan are available in the literature. Colgate-Palmolive scientists used an unconventional method to develop a PNEC of 1,550ng/L (Capdevielle et al., 2008). In contrast, a more traditional and conservative method based on acute algal toxicity has led to the use of PNEC of $4.7 \mathrm{ng} / \mathrm{L}$ (e.g., von der Ohe et al., 2000). Should the latter threshold be considered more appropriate for San Francisco Bay, the few recent ambient Bay surface water measurements available (up to $68 \pm 26 \mathrm{ng} / \mathrm{L}$ ) may suggest cause for concern. However, existing data are too few to trigger reclassification of triclosan within the RMP's CEC risk and management action framework (Sutton et al., 2016). Until more data are generated, triclosan may remain classified as a low concern (Tier II) for San Francisco Bay.

Table 1. Occurrence of EDCs and PhACs in freshwater fish in Lake Skadar lake.

\begin{tabular}{|c|c|c|c|c|c|c|c|c|}
\hline $\begin{array}{l}\text { Sample name } \\
\text { EDCs ng/g }\end{array}$ & $\begin{array}{c}\text { Rutilus } \\
\text { prespensis }\end{array}$ & $\begin{array}{l}\text { Squalius } \\
\text { platyceps }\end{array}$ & $\begin{array}{l}\text { Scardinius } \\
\text { knezevici }\end{array}$ & $\begin{array}{c}\text { Chondrostoma } \\
\text { ohridanum }\end{array}$ & $\begin{array}{c}\text { Ciprinus } \\
\text { carpio }\end{array}$ & $\begin{array}{l}\text { Alburnus } \\
\text { scoranza }\end{array}$ & MDL & MQL \\
\hline Caffeine & $<\mathrm{MDL}$ & $<\mathrm{MDL}$ & $<\mathrm{MDL}$ & $<\mathrm{MDL}$ & $<\mathrm{MDL}$ & $<\mathrm{MDL}$ & 0,3255 & 1,0849 \\
\hline Progesterone & $<\mathrm{MDL}$ & $<\mathrm{MDL}$ & $<\mathrm{MDL}$ & $<\mathrm{MDL}$ & $<\mathrm{MDL}$ & $<\mathrm{MDL}$ & 0,0158 & 0,0526 \\
\hline Levonorgestrel & $<\mathrm{MDL}$ & $<\mathrm{MDL}$ & $<\mathrm{MDL}$ & $<\mathrm{MDL}$ & $<\mathrm{MDL}$ & $<\mathrm{MDL}$ & 0,0002 & 0,0006 \\
\hline TCEP & $<\mathrm{MDL}$ & $<\mathrm{MDL}$ & $<\mathrm{MDL}$ & $<\mathrm{MDL}$ & $<\mathrm{MDL}$ & $<\mathrm{MDL}$ & 0,25 & 0,84 \\
\hline TBEP & $<\mathrm{MQL}$ & $<\mathrm{MQL}$ & $<\mathrm{MQL}$ & $<\mathrm{MQL}$ & $<\mathrm{MQL}$ & $<\mathrm{MQL}$ & 0,07 & 0,27 \\
\hline TCCP & $<\mathrm{MQL}$ & $<\mathrm{MQL}$ & $<\mathrm{MQL}$ & $<\mathrm{MQL}$ & $<\mathrm{MQL}$ & $<\mathrm{MQL}$ & 25,4 & 84,8 \\
\hline Estrone & $<\mathrm{MDL}$ & $<\mathrm{MDL}$ & $<\mathrm{MDL}$ & $<\mathrm{MDL}$ & $<\mathrm{MDL}$ & $<\mathrm{MDL}$ & 0,003 & 0,0099 \\
\hline $17 \beta$-Estradiol & $<\mathrm{MDL}$ & $<\mathrm{MDL}$ & $<\mathrm{MDL}$ & $<\mathrm{MDL}$ & $<\mathrm{MDL}$ & $<\mathrm{MDL}$ & 0,01 & 0,05 \\
\hline Estriol & $<\mathrm{MDL}$ & $<\mathrm{MDL}$ & $<\mathrm{MDL}$ & $<\mathrm{MDL}$ & $<\mathrm{MDL}$ & $<\mathrm{MDL}$ & 0,0002 & 0,0007 \\
\hline $\begin{array}{c}17-\alpha- \\
\text { Ethinylestradiol }\end{array}$ & $<\mathrm{MDL}$ & $<\mathrm{MDL}$ & $<\mathrm{MDL}$ & $<\mathrm{MDL}$ & $<\mathrm{MDL}$ & $<\mathrm{MDL}$ & 0,0004 & 0,0014 \\
\hline Estrone-3-sulfate & $<\mathrm{MDL}$ & $<\mathrm{MDL}$ & $<\mathrm{MDL}$ & $<\mathrm{MDL}$ & $<\mathrm{MDL}$ & $<\mathrm{MDL}$ & 0,0007 & 0,0022 \\
\hline Bisphenol A & $<\mathrm{MQL}$ & $<\mathrm{MQL}$ & $<\mathrm{MQL}$ & $<\mathrm{MQL}$ & $<\mathrm{MQL}$ & $<\mathrm{MQL}$ & 0,02 & 0,07 \\
\hline Triclosan & $<\mathrm{MQL}$ & $<\mathrm{MQL}$ & $<\mathrm{MQL}$ & $<\mathrm{MQL}$ & $<\mathrm{MQL}$ & $14,1 \pm 1,3$ & 0,0018 & 0,0061 \\
\hline Methylparaben & $<\mathrm{MDL}$ & $<\mathrm{MDL}$ & $<\mathrm{MDL}$ & $<\mathrm{MDL}$ & $<\mathrm{MDL}$ & $<\mathrm{MDL}$ & 0,01 & 0,03 \\
\hline
\end{tabular}




\begin{tabular}{|c|c|c|c|c|c|c|c|c|}
\hline $\begin{array}{l}\text { Sample name } \\
\text { PhACs ng/g }\end{array}$ & $\begin{array}{c}\text { Rutilus } \\
\text { prespensis }\end{array}$ & Squaliusplatyceps & $\begin{array}{l}\text { Scardinius } \\
\text { knezevici }\end{array}$ & Chondrostomaohridanum & $\begin{array}{c}\text { Ciprinus } \\
\text { carpio }\end{array}$ & $\begin{array}{l}\text { Alburnus } \\
\text { scoranza }\end{array}$ & MDL & MQL \\
\hline Atenolol & $<\mathrm{MDL}$ & $<\mathrm{MDL}$ & $<\mathrm{MDL}$ & $<\mathrm{MDL}$ & $<\mathrm{MDL}$ & $<\mathrm{MDL}$ & 0,01 & 0,02 \\
\hline Carazolol & $<\mathrm{MDL}$ & $<\mathrm{MDL}$ & $<\mathrm{MDL}$ & $<\mathrm{MDL}$ & $<\mathrm{MDL}$ & $<\mathrm{MDL}$ & 0,01 & 0,02 \\
\hline Metropolol & $<\mathrm{MQL}$ & $<\mathrm{MDL}$ & $<\mathrm{MQL}$ & $<\mathrm{MDL}$ & $<\mathrm{MQL}$ & $<\mathrm{MQL}$ & 0,1 & 0,35 \\
\hline Nadolol & $<\mathrm{MQL}$ & $<\mathrm{MQL}$ & $<\mathrm{MQL}$ & $<\mathrm{MQL}$ & $<\mathrm{MQL}$ & $<\mathrm{MQL}$ & 0,31 & 1,04 \\
\hline Propanolol & $<\mathrm{MDL}$ & $<\mathrm{MDL}$ & $<\mathrm{MQL}$ & $<\mathrm{MQL}$ & $<\mathrm{MQL}$ & $<\mathrm{MQL}$ & 0,09 & 0,29 \\
\hline Sotalol & $<\mathrm{MDL}$ & $<\mathrm{MDL}$ & $<\mathrm{MDL}$ & $<\mathrm{MDL}$ & $<\mathrm{MDL}$ & $<\mathrm{MDL}$ & 0,08 & 0,26 \\
\hline Carbamazepine & $<\mathrm{MDL}$ & $<\mathrm{MDL}$ & $<\mathrm{MDL}$ & $<\mathrm{MDL}$ & $<\mathrm{MDL}$ & $<\mathrm{MDL}$ & 0,05 & 0,17 \\
\hline Citalopram & $<\mathrm{MDL}$ & $<\mathrm{MDL}$ & $<\mathrm{MDL}$ & $<\mathrm{MDL}$ & $<\mathrm{MDL}$ & $<\mathrm{MDL}$ & 0,12 & 0,4 \\
\hline Diazepam & $<\mathrm{MDL}$ & $<\mathrm{MDL}$ & <MQL & $<\mathrm{MDL}$ & $<\mathrm{MDL}$ & $<\mathrm{MDL}$ & 0,03 & 0,1 \\
\hline 10,11-ЕрохуCBZ & $<\mathrm{MDL}$ & $<\mathrm{MDL}$ & $<\mathrm{MQL}$ & $<\mathrm{MDL}$ & $<\mathrm{MQL}$ & $<\mathrm{MDL}$ & 0,02 & 0,05 \\
\hline 2-HydroxyCBZ & $<\mathrm{MDL}$ & $<\mathrm{MDL}$ & $<\mathrm{MDL}$ & $<\mathrm{MDL}$ & $<\mathrm{MDL}$ & $<\mathrm{MDL}$ & 0,01 & 0,03 \\
\hline Lorazepam & $<\mathrm{MDL}$ & $<\mathrm{MDL}$ & $<\mathrm{MDL}$ & $<\mathrm{MDL}$ & $<\mathrm{MDL}$ & $<\mathrm{MDL}$ & 0,06 & 0,2 \\
\hline Sertraline & $<\mathrm{MDL}$ & $<\mathrm{MDL}$ & $<\mathrm{MDL}$ & $<\mathrm{MDL}$ & $<\mathrm{MDL}$ & $<\mathrm{MDL}$ & 0,25 & 0,83 \\
\hline Venlafaxine & $<\mathrm{MDL}$ & $<\mathrm{MDL}$ & $<\mathrm{MDL}$ & $<\mathrm{MDL}$ & $<\mathrm{MDL}$ & $<\mathrm{MDL}$ & 0,01 & 0,03 \\
\hline Clopidrogel & $<\mathrm{MDL}$ & $<\mathrm{MDL}$ & $<\mathrm{MDL}$ & $<\mathrm{MDL}$ & $<\mathrm{MDL}$ & $<\mathrm{MDL}$ & 0,01 & 0,04 \\
\hline Codeine & $<\mathrm{MDL}$ & $<\mathrm{MDL}$ & $<\mathrm{MDL}$ & $<\mathrm{MDL}$ & $<\mathrm{MDL}$ & $<\mathrm{MDL}$ & 0,02 & 0,06 \\
\hline Levamisole & $<\mathrm{MDL}$ & $<\mathrm{MDL}$ & $<\mathrm{MDL}$ & $<\mathrm{MDL}$ & $<\mathrm{MDL}$ & $<\mathrm{MDL}$ & 0,02 & 0,05 \\
\hline Salbutamol & $<\mathrm{MDL}$ & $<\mathrm{MDL}$ & $<\mathrm{MDL}$ & $<\mathrm{MDL}$ & $<\mathrm{MDL}$ & $<\mathrm{MDL}$ & 0,01 & 0,04 \\
\hline Diclofenac & $<\mathrm{MDL}$ & $<\mathrm{MDL}$ & $<\mathrm{MDL}$ & $<\mathrm{MDL}$ & $<\mathrm{MDL}$ & $<\mathrm{MDL}$ & 1,73 & 5,77 \\
\hline Hydrochlorothiazide & $<\mathrm{MDL}$ & $<\mathrm{MDL}$ & $<\mathrm{MDL}$ & $<\mathrm{MDL}$ & $<\mathrm{MDL}$ & $<\mathrm{MDL}$ & 0,01 & 0,02 \\
\hline
\end{tabular}

\section{CONCLUSION}

After the detailed research of PhACs and EDCs in the fish tissues (Rutilus prespensis, Squalius platyceps, Scardinius knezevici, Chondrostoma ohridanum, Cyprinu scarpio and Alburnus scoranza) it is determined that the concentration of researched distributors are found in MDL and MQL. Examined fish are a part of Skadar lake fauna, and are typical representatives. Economically, they are the most important fish. Exception to this research is detected concentration of triclosan $(14,1 \pm 1,3 \mathrm{ng} / \mathrm{g})$ in the tissue of fish Alburnus scoranza. It is considered that the specific habitat and diet of this fish caused these results in its muscle tissue. Further detailed research is needed to establish the source of the PhACs and EDCs.

\section{REFERENCES}

Bianco, P. G. \& Kottelat, M. 2005. Scardiniusknezevici, a new species of rudd from Lake Skadar, Montenegro (Teleostei: Cyprinidae). Ichtyol. Explor. Freshwat.

Bonaparte, C. L. 1841. Aspius alburnus (aspius alborella) - In Iconografiadella fauna italica Pesci, Salvucci.

Beeton, A. M. \& Karaman, G. 1981.The biota and limnology of Lake Skadar. Titograd GRO Prosveta, Beograd. 
Brooks, B. W. 2005. Determination of select antidepressants in fish from an effluent-dominated stream. Environ Toxicol Chem.

Deighton, C. G. \& Ternes, T. A. 1999. Pharmaceuticals and personal care products in the environment: Agents of subtle change? Environmental Health Perspectives.

Capdevielle, M, Egmond, R. V., Whelan, M., Versteeg, D., Hofmann-Kamensky, M., Inauen,J., Cunningham, V. \& Voltering, D. 2008. Consideration of exposure and species sensitivity of triclosan in the freshwater environment. Integr Environ Assess Manag.

Chalew, T. E. A. \& Halden, R. U. 2009. Environmental exposure of aquatic and terrestrial biota to triclosan and triclocarban. Journal of the American Water Resources Association (451).

Drecun, D. \& Miranovic, M. 1962. Ulov ribe na Skadarskom jezeru 1947-1960 godine. Hydrobiologia Montenegrina.

Gros, M., Petrovic, M. \& Barcelo, D. 2009. Tracing Pharmaceutical Residues of Different Therapeutic Classes in Environmental Waters by Using Liquid Chromatography/Quadrupole Linear Ion Trap Mass Spectrometry and Automated Library Searching. Analytical Chemistry.

Govindaraj, S., Karthik, R., Krishna, K., Selvaraj, S. S. \& Babu, R. R. 2014. Triclosan in Fresh Water Fish Gibelion Catla from the Kaveri River, India, and Its Consumption Risk Assessment. Environmental Forensics Volume.

Karaman, S. 1924. Pisces Macedoniae. Split.

Kastratovic, V., Krivokapic, S., Bigovic, M., Djurovic, D. \& Blagojevic, N. 2014. Bioaccumulation and translocation of heavy metals by Ceratophyllum demersum from Skadar Lake, Montenegro. J Serb Chem Soc.

Linnaeus, C. 1758. Systemanaturae per regna trianaturae, secundum classes, ordines, genera, species, cum characteribus, differentiis, synonymis, locis. Tomus I.

Fent, K., Weston, A. A. \& Caminada, D. 2006. Ecotoxicology of human pharmaceuticals. Aquatic Toxicology.

Huerta, B., Jakimska, A., Gros, M., Rodriguez-Mozaz, S. \& Barcelo, D. 2013. Analysis of multi-class pharmaceuticals in fish tissues by ultra-high-performance liquid chromatography tandem mass spectrometry. Journal of Chromatography A.

Huerta, B., Rodriguez-Mozaz, S. \& Barcelo, D. 2012. Pharmaceuticals in biota in the aquatic environment: analytical methods and environmental implications. Anal BioanalChem.

Ohe, T., Hirobe, M. \& Mashino, T. 2000. Novel metabolic pathway of estrone and 17b-estradiol catalyzed by cytochrome P-450. Drug Metab Dispos.
Perovic, A., Perovic, S., Erdinger, L. \& Hollert, H. 2012. Assessment of genotoxic potential of the Lake Skadar sediments extracts using the comet assay with fish cell line RTL-W1 and Ames test. Arch BiolSci.

Petrovic, D., Jancic, D., Furdek, M., Mikac, N. \& Krivokapic, S. 2016. Aquatic plant Trapanatans L. as bioindicator of trace metal contamination in a freshwater Lake (Skadar Lake, Montenegro). Acta Bot Croat.

Rastall, A. C., Neziri, A., Vukovic, Z., Jung, C., Mijovic, S., Hollert, H., Nikcevic, S. \& Erdinger, L. 2004. The identification of readily bioavailable pollutions in Lake Shkodra/Skadar using Semipermeable membrane devices (SPMDs), bioassays and chemical analysis. Environ SciPollut Res Skadarsko jezero (Site 3YU003) In: A directory of wetlands of International importance 2002. The Ramsar Convention Bureau. Gland, Switzerland.

Rakocevic-Nedovic, J. \& Hollert, H. 2005. Phytoplankton community and chlorophyll a as trophic state indices of Lake Skadar (Montenegro, Balkan). Environ SciPollut Res.

Stesevic, D., Feiler, U., Sundic, D., Mijovic, S., Erdinger, L., Seiler, T. B., Heininger, P. \& Hollert, H. 2007. Application of a new sediment contact test with Myriophyllum aquaticum and of the aquatic Lemna test to assess the sediment quality of Lake Skadar.J Soils Sediments.

Sutton, R., Mason, S. A., Stanek, S. K., Willis-Norton, E., Wren, I. F. \& Box, C. 2016. Microplastic contamination in the San Francisco Bay, California, USA.Mar Pollut Bull.

Tatarazako, N., Ishibashi, H., Teshima, K., Kishi, K. \& Arizono, K. 2004. Effects of triclosan on various aquatic organisms. Environ Sci.

Ternes, T. A. 1998. Occurrence of drugs in German sewage treatment plants and rivers. Water Research.

Ximei, L., Xiangping, N., Guangguo, Y., Taicheng, A. \& Kaibing, L. 2013. Assessment of toxic effects of triclosan on the swordtail fish (Xiphophorus helleri) by a multi-biomarker approach.Chemosphere.

Zupancic, P., Maric, D., Naseka, A. M. \& Bogutskaya, N. G. 2010. Squalius platyceps, a new species of fish (Actinopterygii: Cyprinidae) from the Skadar Lake basin. Zoosystematica Rossica.

Zwiener, C. \& Frimmel, F. 2004. LC-MS analysis in the aquatic environment and in water treatment - a critical review - Part I: Instrumentation and general aspects of analysis and detection. Analytical and Bioanalytical Chemistry.

Vemic, M., Rousseau, D., Laing, G. D. \& Lens, P. 2014. Distribution and fate of metals in the Montenegrin part of Lake Skadar. Int J Sediment Res. 